\title{
Taxonomy and distribution of species of the genus Acanthus (Acanthaceae) in mangroves of the Andaman and Nicobar Islands, India
}

\author{
P. RAGAVAN ${ }^{1}$, ALOK SAXENA ${ }^{2}$, P.M. MOHAN ${ }^{1}$, R.S.C. JAYARAJ ${ }^{3}$, K. RAVICHANDRAN ${ }^{4}$ \\ ${ }^{1}$ Department of Ocean studies and Marine Biology, Pondicherry University, Brookshabad Campus, Port Blair, A \& N Islands, India Tel.: +91-3192- \\ 213126/261566. Fax +91-3192-261568, ’email: van.ragavan@gmail.com \\ ${ }^{2}$ Indira Gandhi National Forest Academy, Dehradun, Uttarakhand, India \\ ${ }^{3}$ Rain Forest Research Institute, Jorhat, Assam, India \\ ${ }^{4}$ Department of Environment and Forests, Andaman and Nicobar Administration, Port Blair, A \& N Islands, India
}

Manuscript received: 3 September 2015. Revision accepted: 16 September 2015.

\begin{abstract}
Ragavan P, Saxena A, Mohan PM, Jayaraj RSC, Ravichandran K. 2015. Taxonomy and distribution of species of the genus Acanthus (Acanthaceae) in mangroves of the Andaman and Nicobar Islands, India. Biodiversitas 16: 225-237. A recent floristic survey revealed the occurrence of three species of Acanthus in mangroves of the Andaman and Nicobar Islands, India. Of these Acanthus ilicifolius and A. ebracteatus are shrubs, whereas A. volubilis is a climbing shrub. All the three Acanthus species were recorded from the Andaman Islands, but only A. ilicifolius from the Nicobar Islands. A. volubilis is easily distinguished from other two species by its unarmed and twining delicate sprawling stems, un-serrated elliptical leaves, white corolla and absence of bracteoles. A. ilicifolius and A. ebracteatus are differentiated based on the presence and absences of bracteoles, corolla color, and position of Inflorescence and direction of stem axial spines. A key for the species of Acanthus of the Andaman and Nicobar Islands is also provided.
\end{abstract}

Keywords: Acanthus, Andaman and Nicobar Islands, India, taxonomy

\section{INTRODUCTION}

The genus Acanthus L. belonging to the family Acanthaceae is an Old World genus native of tropics and subtropics with about 30 species. It is often distinguished from the related genera by spiny leaves, spicate terminal inflorescences, two bracteoles and uniform anthers (Duke 2006). Four species viz., A. ebracteatus Vahl, A. ilicifolius L., A. volubilis Wall. and A. xiamenensis are known from mangrove communities and are classified as true mangrove species (Polidoro et al. 2010). Of these A. xiamenensis is endemic to China and all the other species are common in Indo West Pacific (IWP) region. However, the taxonomical identity of $A$. xiamenensis in China is not clear; for instance Wang and Wang (2007) have treated A. xiamenensis and $A$. ilicifolius as the same species. In India all the three Acanthus species are reported in the Andaman and Nicobar Islands (ANI). Generally Acanthus species occur either as an under storey in inner mangrove area or frontal thickets on edges of the tidal creek in middle to upper estuarine areas, although they do occur in lower estuarine position (Duke 2006).

Among the three species of Acanthus the taxonomical distinction between A. ilicifolius and A. ebracteatus still not clear in India (Kathiresan 2010). For instance, Remadevi and Binojkumar (2000) contended that many specimens identified and indexed as A. ilicifolius in Indian herbaria are actually $A$. ebracteatus, but their identification has been questioned by Anupama and Sivadasan (2004). Further Mandal and Naskar (2008) noted that A. volubilis considered as extinct in India has been recorded again with its very limited population from Sundarbans. Kathiresan (2008) has not included this species in his report. Thus the taxonomy and distribution of Acanthus spp., is not well understood in India as well as in the ANI.

Species of Acanthus were first reported from the ANI by Parkinson (1923). He recognized all the three species discussed in this account, however he did not provide the detailed taxonomical description. He noted that $A$. ilicifolius was common and that a few A. ebracteatus were found along with $A$. ilicifolius and that $A$. volubilis was uncommon found in Bomlungta and Yeratilajig. By the description and the key given by him it is understood that he identified the Acanthus species based on serration in the leaves and flower color, but these two characters are variable in Acanthus spp. After that all the three Acanthus species were listed in the mangrove floral list of the ANI by Sahni (1958), Dagar (1987), Mall et al. (1987), Das and Dev Roy (1989), Dagar et al. (1991), Singh and Garge (1993), Dagar and Singh (1999), Singh (2003), Debnath (2004), and Dam Roy et al. (2009). Among them Dagar et al. (1991) described the species of Acanthus with locality data. Mall et al. (1987) and Singh and Garge (1993) described two species and noted that $A$. volubilis was not encountered in the ANI but included it based on the reports of Parkinson (1923) and Thothathri (1962). Thothathri (1962) reported A. volubilis from Campbell Bay, Great Nicobar Island but the specimen deposited by him shows that he had misidentified spineless form of A. ilicifolius as A. volubilis. Dam Roy et al. (2009) also described all the three Acanthus species but later it was found that they misidentified spineless form of A. ilicifolius as A. volubilis 
(Goutham Bharathi et al. 2014; Ragavan et al. 2014) Recently Goutham Bharathi et al. (2014) reported two species viz., A. ilicifolius and A. ebracteatus, and further noted that $A$. volubilis was recorded nearly three decades ago as a rare species. Ragavan et al. (2014) reported the occurrence all the three species of Acanthus in the ANI but they did not provide detailed taxonomical description. Hence, in the present study Acanthus spp., in the ANI are described, illustrated and compared to provide the taxonomical distinction and to document their distribution.
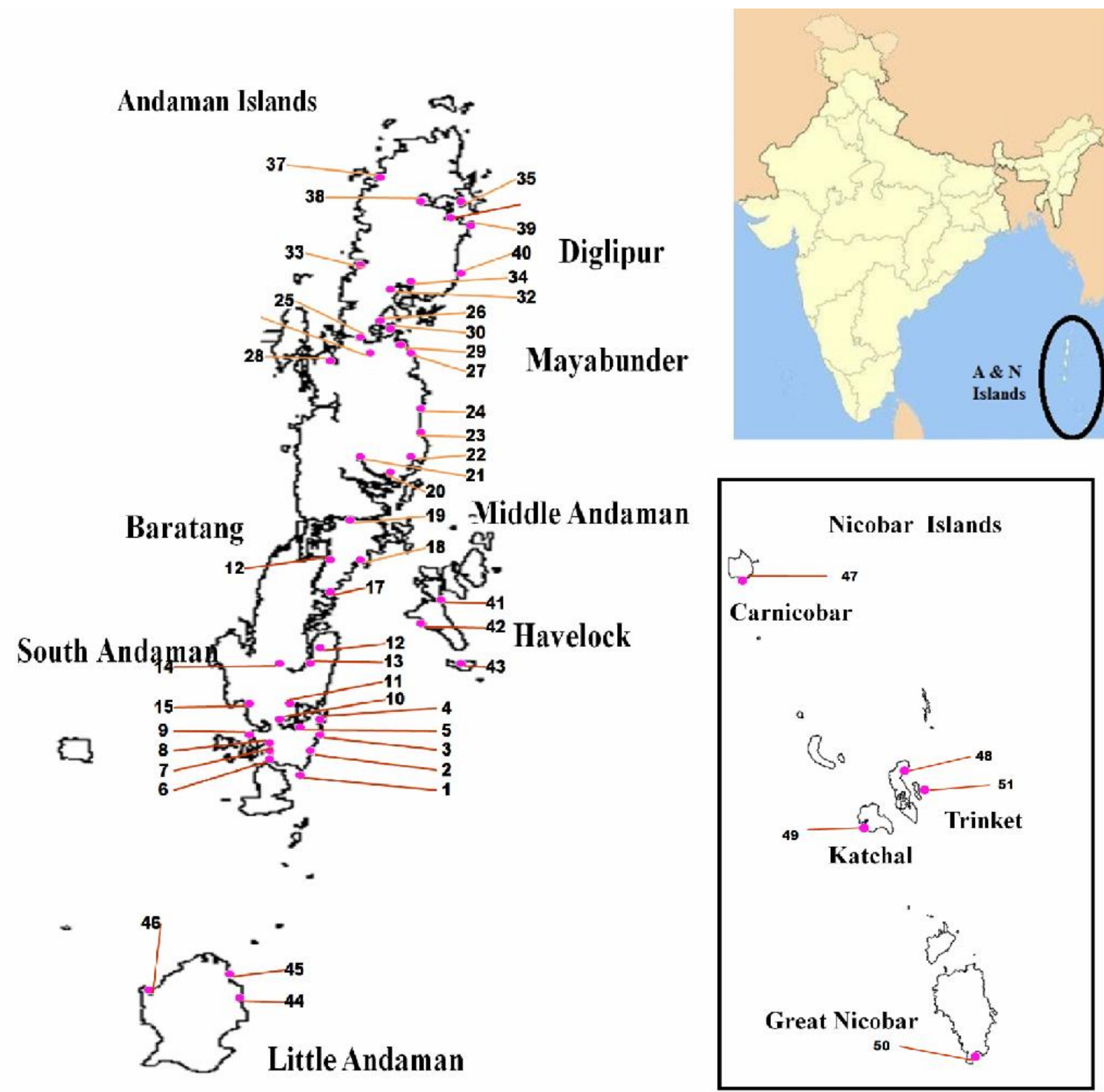

Figure 1. Map showing surveyed sites in the ANI. South Andaman: 1. Chidiyatapu, 2. Burmanallah, 3. Beadonabad, 4. Corbyn's Cove, 5. Sippighat, 6. Manjeri, 7. Guptapara, 8. Manglutan, 9. Wandoor, 10. Ograbraj, 11. Bambooflat Creek, 12. Wright Myo creek, 13. Shoal Bay Creek, 14. Jirkatang, 15. Tirur; Baratang: 16. Middle Strait, 17. Wrafter's Creek, 18. Baludera; Middle Andaman: 19. Kadamtala Creek, 20. Yerrata Creek, 21. Shyamkund Creek, 22. Dhaninallah Creek, 23. Rangat Bay, 24. Panchawati; Mayabunder: 25. Austin Creek, 26. Mohanpur Creek, 27. Karmatang Creek, 28. Chainpur Creek, 29. Rampur, 30. Danapur, 31. Tugapur; Diglipur: 32. Parangara Creek, 33. Kishorinagar Creek, 34. Kalighat Creek, 35. Smith Island, 36. Ariel bay, 37. Radhanagar, 38. Lakshmipur, 39. Durgapur,, 40. Ramnagar; Havelock: 41. Govindnagar, 42. Radhanagar, 43. Neil Island; Little Andaman: 44. V.K Pur creek, 45. Dugong Creek, 46. Jackson Creek; Nicobar islands: 47. Car Nicobar, 48. Kamorta, 49. Katchal, 50. Campbell Bay, 51. Trinket island 


\section{MATERIALS AND METHODS}

During 2009-2013 qualitative survey was carried out randomly over 51 sites in 8 forest divisions of the ANI to record the species occurrences in the mangroves of the ANI (Figure 1). All sites have been visited at least once at the time of flowering of the different species to crosscheck identification with flower-based diagnostic features. Site access was achieved using a combination of road plus small boat transport to gain access to the extensive range of mangrove area.

Plant collections were made of all Acanthus taxa encountered from the range of sites visited. For each Acanthus species both numeric and multistate attributes of a wide range of vegetative and reproductive morphological characters were observed from one or two individuals at each site. All measurements and observations were made from fresh material for making key for Acanthus spp. The morphological measures and observations were developed and standardized during prior assessments of this genus. For each species 2-5 specimens were sampled with flowers and fruits for herbarium preparation. Herbarium specimen has been prepared and deposited to the National Botanical Collection of Andaman Nicobar Regional Centre, Botanical Survey of India, Port Blair.

\section{RESULTS AND DISCUSSION}

\section{Key to Acanthus species in ANI}

1. Bracteoles present Bracteoles absent or minute 2

2. Inflorescences terminal and axial, flowers light blue to dark or violet (rarely white), stem axial present or absent, if present always facing upward .... A. ilicifolius

3. Inflorescences terminal, flowers white, stem axial spine absent A. volubilis

4. Inflorescences terminal, flowers white, stem axial spines facing downwards A. ebracteatus

\section{Acanthus ilicifolius L.-Linnaeus C. 1753. Sp. PI. 2: 639.} (Figure 2)

Acanthus doloarin Blanco-Blanco, F.M. 1837. Fl. Filip. 487. Acanthus neoguineensis Engl.-Engler, H.G.A. 1886. Bot. Jahrb. Syst. 7: 474.

Dilivaria ilicifolia (L.) Juss.-Jussieu, A.L. 1789.Gen. Pl. 103.

Shrub: height up to $3 \mathrm{~m}$ (Figure 2A). Stem: thick, green, light green or purple, sparsely branched and stem axial spine either present or absent, if present always facing upward (Figure 2E). Roots: occasionally above ground or prop roots on lower parts of reclining stem (Figure 2D). Leaves: simple, opposite, lanceolate to broadly lanceolate, margin either entire or spiny and dentate, leaf base attenuate, leaf tip acute and narrowly pointed with or without spiny edge, presence of spines with greater sunlight and exposure, size variable, $6-30 \times 1.5-6 \mathrm{~cm}$, ratio of length to width is greater than 2; petiole short, green, 0.5-2 cm long. Inflorescences: both terminal (Figure 2B) and axial (Figure 2C), terminal inflorescences longer than axial, up to $15 \mathrm{~cm}$ long, axial inflorescence smaller than terminal, 5-10 cm long. Mature flower bud: ellipsoidal, 3$3.5 \mathrm{~cm}$ long; bract single, $0.8-1 \times 0.5-0.7 \mathrm{~cm}$ (Figure $2 \mathrm{H}$ ); bracteoles 2, lateral, 0.5-0.8 x 0.2-0.4 cm (Figure 2H); calyx four lobed, outer two lager in size, 1.3-1.5 x 0.8-1.2 $\mathrm{cm}$, enclosing the flower bud, inner lateral lobes narrow, 1 by $0.5-0.8 \mathrm{~cm}$, enclosed by upper and lower lobes; corolla purple or deep purple, rarely white with dark blue median band (Figure 1B and 1I), 3-4 cm x 2-2.5 cm; stamens 4, 2$2.5 \mathrm{~cm}$ long, sub equal with thick hairy connectives; anther medifixed each with 2 cells aggregated around the style, $0.8-1 \mathrm{~cm}$ long, densely ciliated (Figure $2 \mathrm{~F}$ ); ovary bi-locular with 2 superimposed ovules in each loculus; style enclosed by stamens, $2.5-3 \mathrm{~cm}$ long, capitate to pointed stigma exposed (Figure 2G and 2I). Mature fruits: 4 seeded capsule, ovoid, green, shiny, smooth, 3-3.5 x $1 \mathrm{~cm}$ (Figure 2J).

Distribution. Found from India to southern China, tropical Australia and the western Pacific islands, including New Caledonia and the Solomon Islands. Occurs throughout Southeast Asia. In India it is common in both east and west coast. In ANI it is found common in both Andaman Islands and Nicobar Islands.

Habitat and Ecology. Common in landward edges of mangroves just above the high tide mark, also occurs in inner mangroves as understorey. Individuals under shade are not serrated.

Phenology. Flowering February to March; fruiting April to May.

Specimen examined. India, Andaman and Nicobar Islands, South Andaman, Shoal Bay Creek (11 ${ }^{\circ} 47^{\prime} 58.4^{\prime \prime} \mathrm{N}$, 92 43' 03.2"E), P. Ragavan, PBL 30965 and 30966.

\section{Acanthus ebracteatus Vahl-Vahl, M. 1791. Symb. Bot. 2:} 75. (Figure 3)

Acanthus ilicifolius Lour-Loureiro, J. 1790. Fl. Cochinch. 2: 375.

Dilivaria ebracteata (Vahl) Pers.-Persoon, C.H. 1806. Syn. Pl. 2: 179 .

Acanthus ilicifolius var. ebracteatus (Vahl) Benoist-Benoist, R. 1910. Acanthacea nouvelle de Madagascar. Notul. Syst. (Paris) 1: 224-225.

Shrub: height up to $2 \mathrm{~m}$ (Figure 3A). Stem: thick, grey color, sparsely branched, stem axial spines always present and facing downward (Figure 3C). Roots: occasionally above ground or prop roots on lower parts of reclining stem (Figure 3B). Leaves: simple, opposite, broadly elliptic to lanceolate, 10-20 x 3-6 cm, leaf tip acute to obtuse with or without spiny edge, base attenuate, margin either/ or spiny and dentate, presence of spines with greater sunlight and exposure; petiole short $0.5-1.5 \mathrm{~cm}$ long. Inflorescence: terminal always (Figure 3D), never axial. Mature flower bud: ellipsoidal, 1.8-2.2 cm long; bract single not persistent (Figure 3E, K), 0.3-0.5 cm, apex obtuse, bracteoles absent or obscure, $0.3-0.5 \mathrm{~cm}$, apex acute (Figure 3F); calyx four lobed (Figure 3L), 0.6-0.8 cm long, upper lobe larger than lower lobe (Figure 3I), enclosing the flower bud, lateral lobes narrow, enclosed by upper and lower lobes; corolla white, with purple stripe in middle of lower lip (Figure $3 \mathrm{H})$, 0.9-1.5 cm long; stamens 4, 1.2-1.5 cm long, sub 
equal with thick hairy connectives; anther medifixed each with 2 cells aggregated around the style, $0.3-0.5 \mathrm{~cm}$ (Figure $3 \mathrm{M}$ ); ovary bilocular with 2 superimposed ovules in each loculus; style enclosed by stamens, $0.8-1.2 \mathrm{~cm}$ long, capitate to pointed stigma exposed (Figure 3G). Mature fruit: 4 seeded capsule, ovoid, green, shiny, smooth, 2-2.5 x $1 \mathrm{~cm}$ (Figure 3J).

Distribution. From India to tropical Australia, Southeast Asia and the west Pacific islands (e.g. Solomon Islands). In Southeast Asia it has been recorded in Cambodia, Myanmar, the Philippines, Vietnam, Malaysia, Singapore, Indonesia and Papua New Guinea. In India A. ebracteatus occurs in Kerala, Puducherry and ANI. In ANI it is recorded from Sippighat and Shoal Bay Creek in South Andaman Island.

Habitat and Ecology. Common in landward edges of mangroves just above the high tide mark, also occur in inner mangroves as under-storey. Individuals under shade are less serrated

Phenology. Flowering and fruiting occurs throughout the year apparently.

Specimen examined. India, Andaman and Nicobar Islands, South Andaman, Sippighat (11 $36^{\prime} 50.1^{\prime \prime} \mathrm{N}, 92^{\circ} 41^{\prime}$ 22.2"E), P. Ragavan, PBL 30969 and 30970.

\section{Acanthus volubilis Wall-Wallich, N. 1831. Pl. Asiat. Rar. 2: 56. (Figure 4)}

Dilivaria scandens Nees-Nees von Esenbeck CGD.1847. Prodr. 11: 269.

Dilivaria volubilis (Wall.)Nees-Nees von Esenbeck, C.G.D. 1832. Pl. Asiat. Rar. 3: 98.

Twining shrub: length to 2-4 m (Figure 4A). Stem: thin, green, branched, smooth, stem axial spines absent (Figure 4I). Roots: occasionally above ground or prop roots on lower parts of reclining stem (Figure 4G). Leaves: simple, opposite, without spines, succulent, elliptic or oblong lanceolate, leaf tip acute to obtuse with spiny edge, leaf base attenuate, margin entire without spines and dentate (Figure 4B), 5-10 × 2.5-4 cm, ratio of length to width greater than 2; petiole short $0.5-2 \mathrm{~cm}$ long, green. Inflorescence: always terminal (Figure 4C), 8-12 cm long; Mature flower bud: ellipsoidal, 2-2.8 cm long; bract single not persistent; bracteoles absent (Figure 4H); calyx 1-1.3 $\mathrm{cm}$ long, four lobed, upper lobe 1.3 by $0.5 \mathrm{~cm}$, lower lobe 1 $\mathrm{x} 0.4 \mathrm{~cm}$, enclosing the flower bud, lateral lobes narrow, 0.5-0.7 cm long, enclosed by upper and lower lobes (Figure 4J); corolla white, 1.5-2 x 2-2.5 cm (Figure 4D); stamens 4, $1.5 \mathrm{~cm}$ long, sub equal with thick hairy connectives; anther medifixed each with 2 cells aggregated around the style (Figure 4E); ovary bilocular with 2 superimposed ovules in each loculus; style enclosed by stamens, $1-1.5 \mathrm{~cm}$ long, capitate to pointed stigma exposed (Figure 4F). Mature Fruit: 4 seeded capsule, ovoid, green, shiny, smooth, 2-2.5 $\mathrm{x} 1 \mathrm{~cm}$ (Figure 4K).

Distribution. Found from South to Southeast Asia. Recorded in eastern India (Odisha), Sri Lanka and the Andaman Islands, to Myanmar, Indonesia, Cambodia, Malaysia, Singapore, Thailand and Papua New Guinea. In India Acanthus volubilis occurs in ANI and Sundarbans. In ANI it is recorded from Shoal Bay Creek and Jirkatang in South Andaman at confined location.
Habitat and Ecology. Observed in landward edges of mangroves just above the high tide mark flooded during spring tides June.

Phenology. Flowering March to April; fruiting May to

Specimen examined. India, Andaman and Nicobar Islands, South Andaman, Shoal Bay Creek (11 ${ }^{\circ} 47^{\prime} 58.4^{\prime \prime} \mathrm{N}$, 92 43' 03.2"E), P. Ragavan, PBL 30967 and 30968.

\section{Discussion}

Among the three Acanthus species described in this account $A$. volubilis can be easily distinguished from other two species by its unarmed and twining with delicate sprawling stems, un-serrated elliptical leaves, white corolla and absence of bracteoles. However it was found from this study that A. ilicifolius also exhibits un-serrated leaves, stem without axial spines but presence of bract and bracteoles is consistent in A. ilicifolius. So without flower it is difficult to distinguish $A$. volubilis and A. ilicifolius in the ANI. Specimen deposited by Thothathri (1962) and photographs shown in Dam Roy et al. (2009) for $A$. volubilis possess un-serrated leaves and stem without axial spines but flowering and fruiting was not reported by them. This supposes that the only character of the observed specimen used by them to identify the species as $A$. volubilis was spineless leaves and stem. Parkinson (1923) reported A. volubilis from Middle Andaman whereas Dagar et al. (1991) reported it from Baratang Island. In the present study $A$. volubilis was not observed in the above mentioned sites; instead wide variation in A. ilicifolius was observed there. In this study it was recorded from Shoal Bay Creek and Jirkatang in South Andaman, though in past no records are available for the presence of A. volubilis in these two sites.

In this study A. ebracteatus was recorded from South Andaman at two sites viz., Shoal Bay and Sippighat. The species status of $A$. ebracteatus is often doubted by the botanists since the two species viz., A. ilicifolius and $A$. ebracteatus have similar vegetative characteristics and the difference between them is the presence or absence of bracteoles which are often lost at anthesis, and many people have been wary when making identifications (Barker 1986). The taxonomical identity of A. ebracteatus was mainly based on the absence of bracteoles, white color corolla and smaller size of flower and fruits. During the present study it was found that position of inflorescences and direction of stem axial spines at nodes aid the rapid differentiation of A. ilicifolius from A. ebracteatus apart from flower color and presence of bracteoles in the ANI. In A. ebracteatus inflorescences are always terminal and stem axial spines face downwards whereas in A. ilicifolius inflorescences are both terminal and axial and stem axial spines face upwards. Bract and bracteoles are always present and persistent in A. ilicifolius whereas in $A$. ebracteatus bracteoles are absent or minute and bracts are present and both are lost before or at anthesis. Diagnostic characters of Acanthus spp. in the ANI are given in Table 1. 


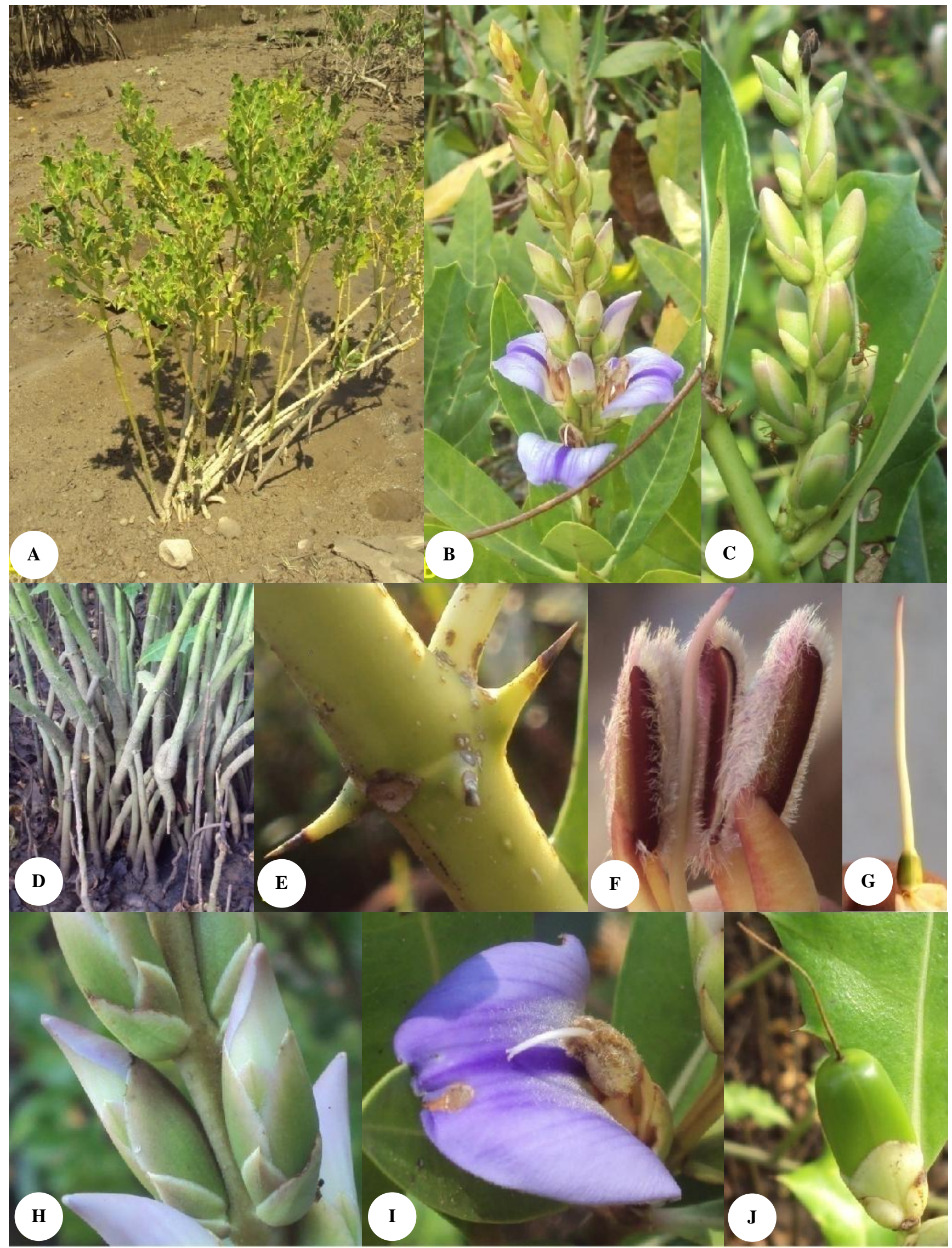

Figure 2. Diagnostic characters of A. ilicifolius. A. Habitat, B. Terminal infloresences, C. Axial inflorescences, D. Stem based with above ground roots, E. Stem axial spines facing upwards, F. Densely ciliated anther, G. Style, H. Presences of bract and bracteoles, I. Blue color corolla, J. Fruit 


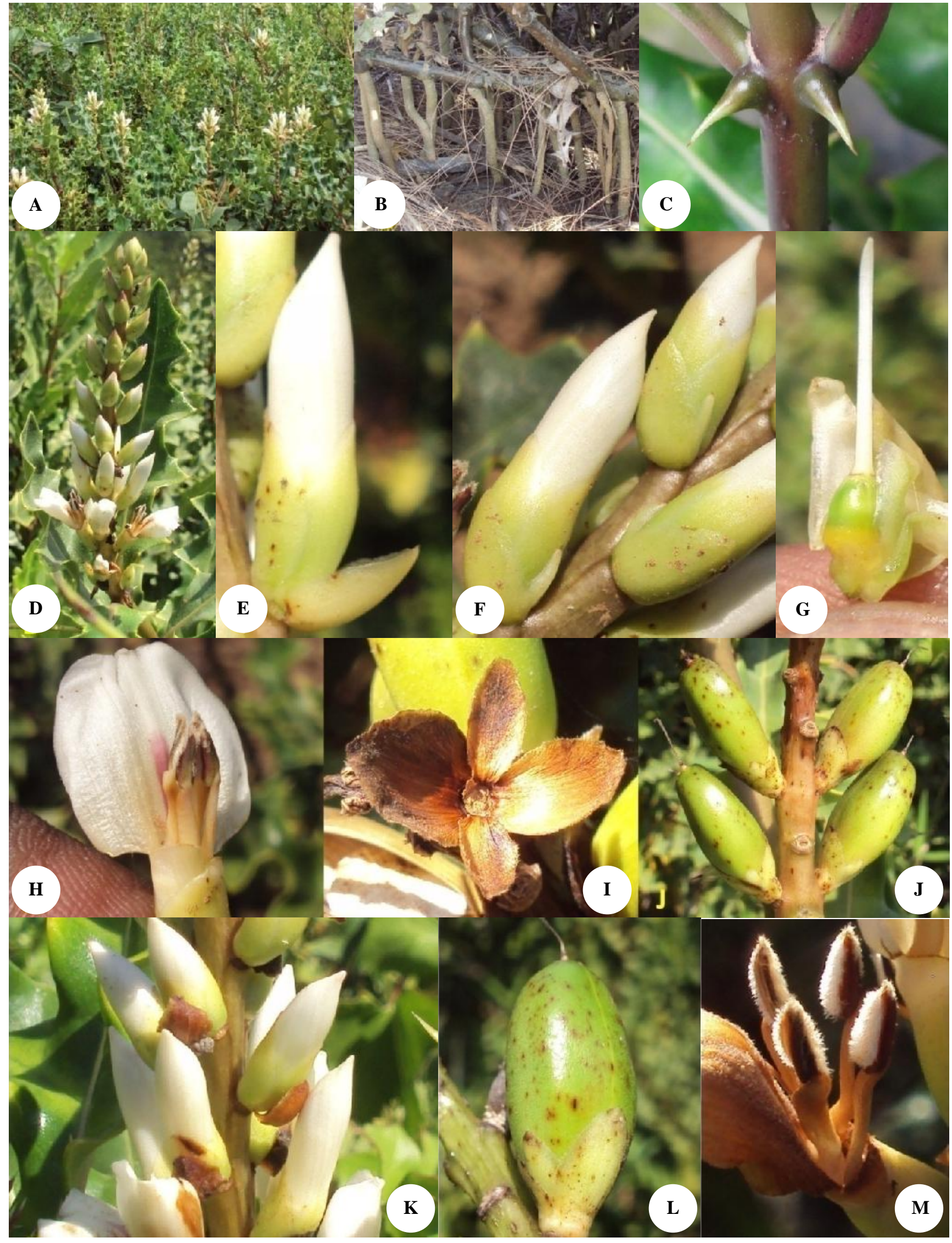

Figure 2. Diagnostic characters of A. ebracteatus: A. Habitat, B. Prop roots, C. Stem axial spine faring downwards, D. Terminal infloresences, E. Flower bud with only bract, F. Flower bud with bract and minute bracteoles, G. Style, H. White corolla with purple stripe in middle of lower lip, I. Calyx lobes, J. Fruits, K. Removal of bract before anthesis, L. Mature fruit without bract and bracteoles, M. Small stamens with densely ciliated anther 


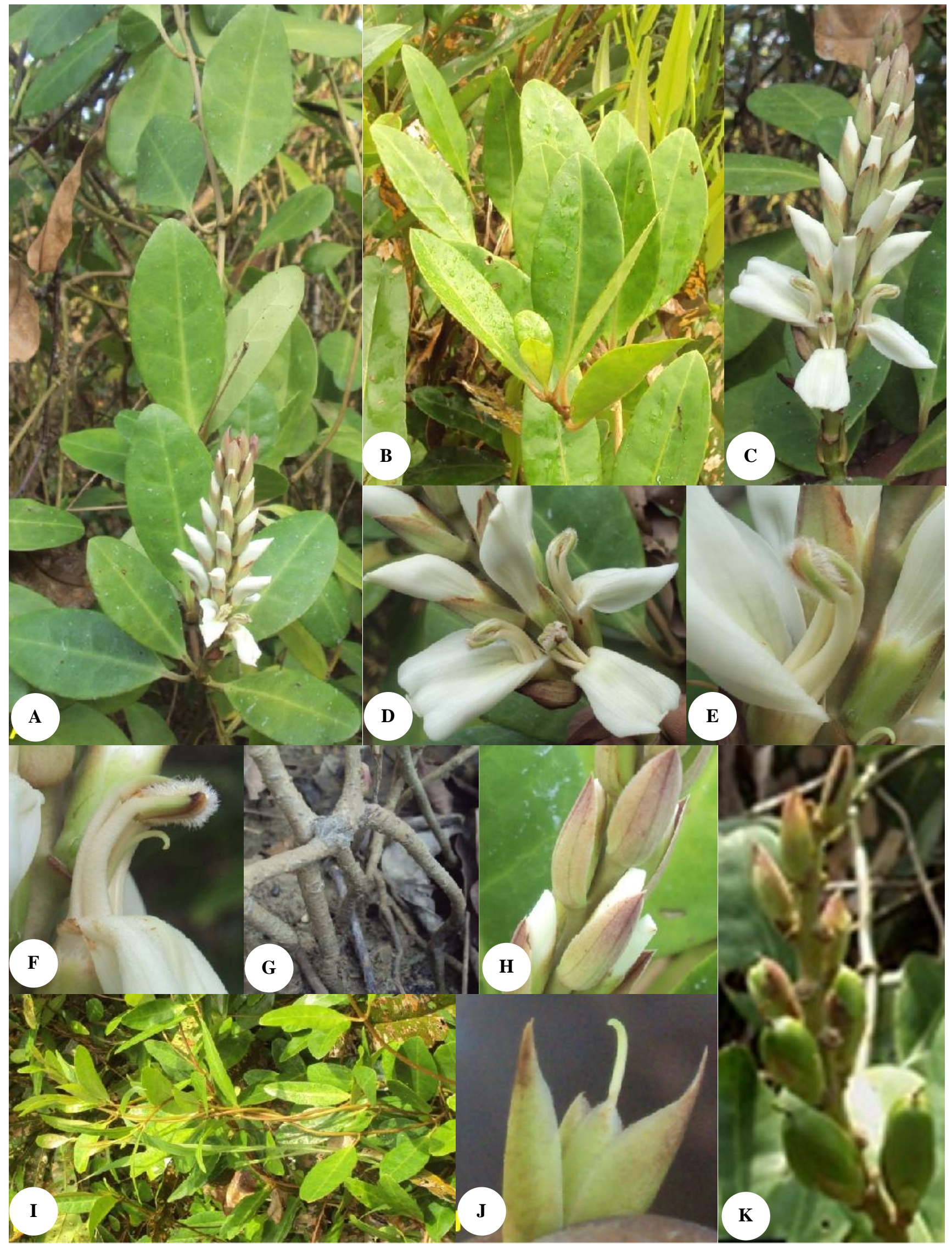

Figure 4. Diagnostic characters of A. volubilis: A. Habitat, B. Leaves, C. Terminal inflorescences, D. White corolla, E. Stamens with densely ciliated anther, F. Style, G. Stilt root, H. Prominent bract, I. Twining smooth stem, J. Calyx lobes, K. Fruits 


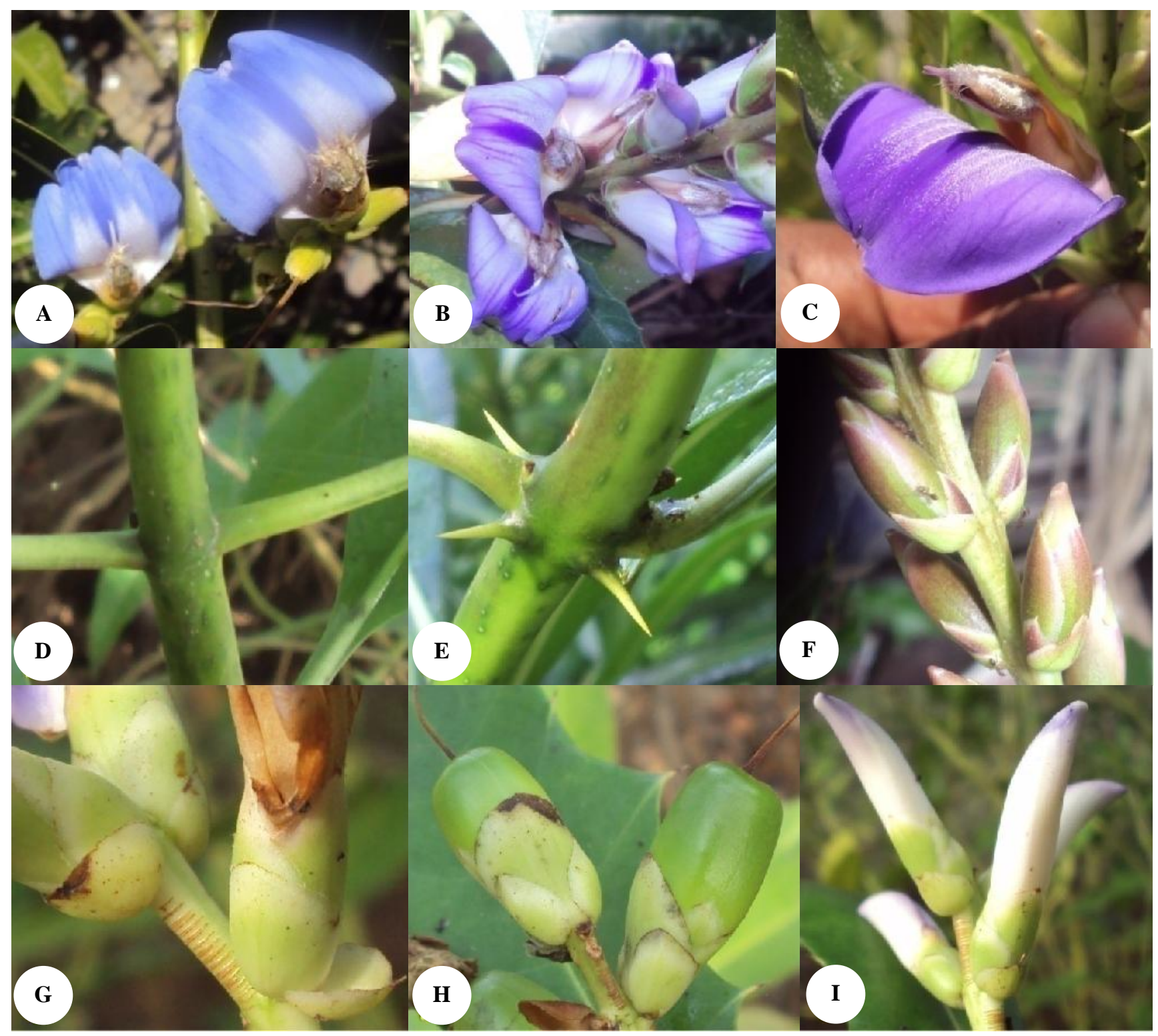

Figure 5. Variation in A. ilicifolius: A. Light blue flower, B. Flower with white margin and median dark blue band, C. Purplish flower, D. Smooth stem without axial spines, E. Stem with axil spines, F. Reddish bract and bracteoles with acute tip, G. Bract and bracteoles with obtuse apex, H. Fruit with persistence bracteoles with obtuse tip, I. Large sized flower

Most of the A. ilicifolius population observed in this study have lanceolate bract and bracteoles with mucronate tip, ciliated margin and medial vein whereas the population observed in Great Nicobar Island possessed ovate bract and bracteoles with ciliated margin and flowers are comparatively larger than that of others (Figure 5G-I) A. ilicifolius specimens have been recorded with stems that are green, purple or of colors in between with or without stem axial spines (Figure 5D and 5E) and color of bract and bracteoles also varied (Figure 5F). Flowers and fruits of $A$. ebracteatus are smaller than that of A. ilicifolius, but flower color of $A$. ilicifolius varied from light to dark blue or violet with dark blue median band (Figure 4A-C). In both $A$. ilicifolius and A. ebracteatus degree of serration in leaves varied with respect to exposure to sun, individuals under shade being less serrated particularly in A. ilicifolius, and wide variation in leaf shape was recorded in the ANI (Figure 6 and 7).

In Table 2 Characters of A. ilicifolius and $A$. ebracteatus described from Malesia, Java, Australia and New Guinea are compared with characters of A. ilicifolius and A. ebracteatus observed in the ANI. This indicates that presence of both terminal and axial inflorescences in $A$. ilicifolius and direction of stem axial spine (downward in A. ebracteatus and upward in A. ilicifolius) are new observation and not recorded for these species. There are marked differences in the size of flower and fruit between A. ilicifolius and A. ebracteatus in the ANI as in Malesia. Axillary thorns are variable in A. ilicifolius of the ANI whereas axillary thorns are more consistent in others places and flower color is variable in all the places. Bract and bracteole's apex is acute and mucronate in most of the 


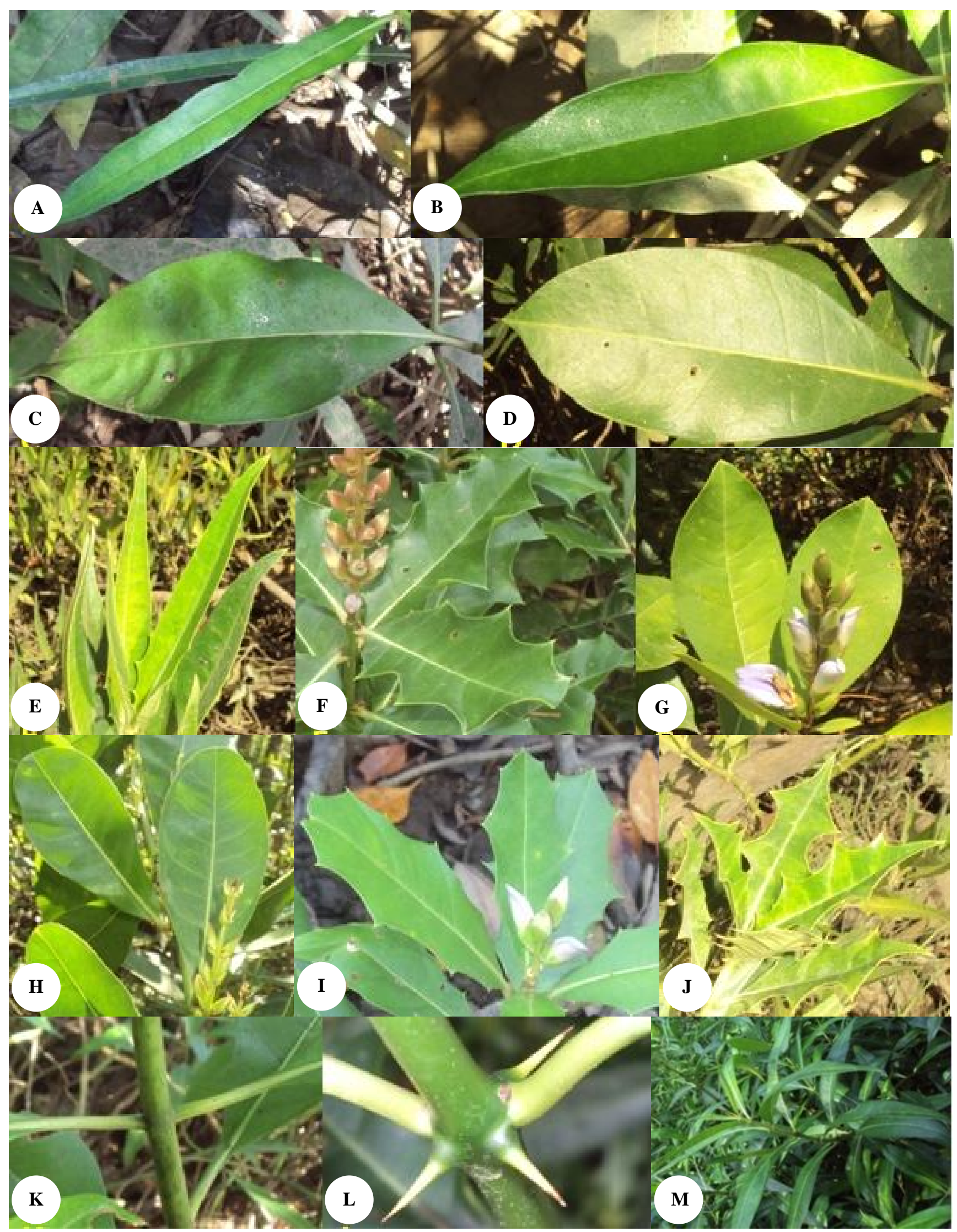

Figure 6. Variation in leaves of A. ilicifolius: A. Smooth needle like leaf, B. Smooth lanceolate like leaf, C and D. Smooth broadly elliptic leaves with acuminate tip, E. Leaves serrated at base only, F. Highly dentate leaves, G. Smooth leaf with acute tip, G. Obovate leaves with rounded tip, I. Moderately serrated and dentate leaves, J. Highly serrated leaves, K. Stem with axial spines, L. Stem with axial spine, M. Smooth leaves with spine axial spines 


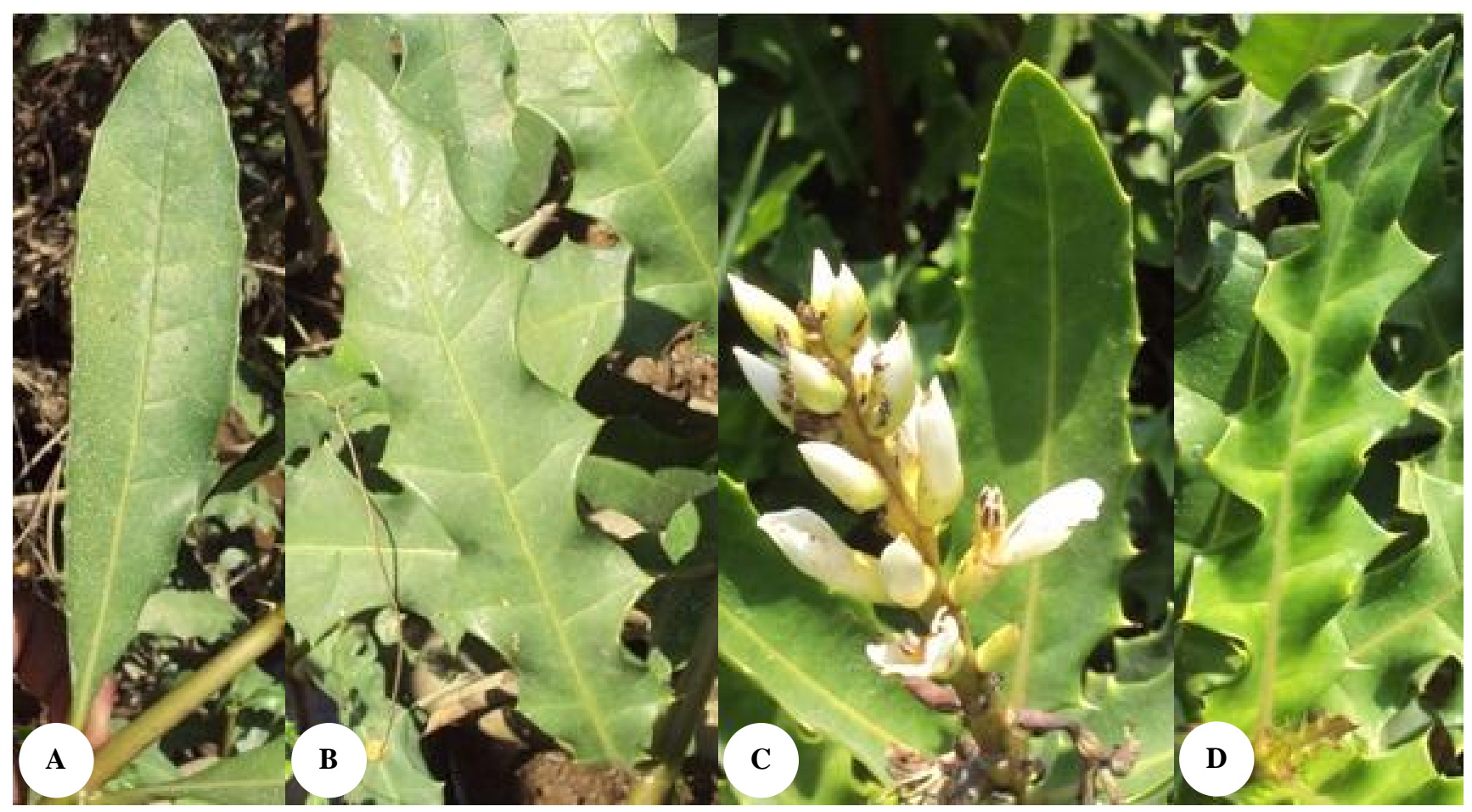

Figure 7. Variation in leaves of A. ebracteatus. A. Leaf with smooth margin, B. Leaf with moderately serrated and denate, C. Leaf with less serrated, D. L with highly serrated and dentate

Table 1. Diagnostic characters of Acanthus species of the ANI

\begin{tabular}{|c|c|c|c|c|}
\hline Components & Characters & A. ilicifolius & A. ebracteatus & A. volubilis \\
\hline \multirow[t]{4}{*}{ Leaves } & Leaf shape & Highly variable lanceolate to obovate & Oblong elliptic & Elliptic \\
\hline & Leaf apex & $\begin{array}{l}\text { Acute to acuminate or rounded with or } \\
\text { without spiny edge }\end{array}$ & Acute with or without spiny edge & $\begin{array}{l}\text { Acute with or without } \\
\text { spiny edge }\end{array}$ \\
\hline & Leaf base & Attenuate & Attenuate & Cuneate \\
\hline & $\begin{array}{l}\text { Leaf } \\
\text { margin }\end{array}$ & Entire to spiny and dentate & Spiny and dentate & Entire \\
\hline \multirow[t]{3}{*}{ Stem } & Texture & Thick & Thick & Thin, twine like \\
\hline & Color & $\begin{array}{l}\text { Variable green, purple or colors in } \\
\text { between }\end{array}$ & Mostly purple, green also & Greenish brown \\
\hline & $\begin{array}{l}\text { Axial } \\
\text { spines }\end{array}$ & $\begin{array}{l}\text { Present or absent, if present always } \\
\text { facing upwards }\end{array}$ & Always resent facing downward & Absent \\
\hline Inflorescences & Position & Terminal and axial & Terminal always & Terminal always \\
\hline \multirow[t]{6}{*}{ Mature flower } & Bud length & $3-3.5 \mathrm{~cm}$ long & $1.8-2.2 \mathrm{~cm}$ long & $2-2.8 \mathrm{~cm}$ long \\
\hline & Bract & Present, single and persistent & Present, single fall before anthesis & $\begin{array}{l}\text { Present, single, fall } \\
\text { before anthesis }\end{array}$ \\
\hline & Bracteoles & Two, lateral, persistent & $\begin{array}{l}\text { Absent or minute, lateral, two, fall } \\
\text { before anthesis }\end{array}$ & Absent \\
\hline & Petal & $\begin{array}{l}\text { Mostly purple, blue or dark blue, } \\
\text { rarely white }\end{array}$ & $\begin{array}{l}\text { White with purple stripe in middle } \\
\text { of lower lip }\end{array}$ & White \\
\hline & Stamens & Four, $2-2.5 \mathrm{~cm}$ long & Four, $1.2-1.5 \mathrm{~cm}$ long & Four $1.2-1.5 \mathrm{~cm}$ long \\
\hline & Style & $2.5-3 \mathrm{~cm}$ long & $0.8-1.2 \mathrm{~cm}$ long & $1-1.5 \mathrm{~cm}$ long \\
\hline \multirow[t]{3}{*}{ Mature fruit } & Shape & Capsule like & Capsule like & Capsule like \\
\hline & Fruit length & $3-3.5 \mathrm{~cm}$ & $2-2.5 \mathrm{~cm}$ & $2-2.5 \mathrm{~cm}$ \\
\hline & Seed & Four seeded & Four seeded & Four seeded \\
\hline
\end{tabular}


Table 2. Comparison of characteristics for A. ilicifolius and A. ebracteatus from Malesia, Australia, New Guinea and ANI

\begin{tabular}{|c|c|c|c|c|c|c|c|c|c|c|}
\hline \multirow[b]{2}{*}{ Characters } & \multicolumn{5}{|c|}{ Acanthus ilicifolius } & \multicolumn{5}{|c|}{ Acanthus ebracteatus } \\
\hline & $\begin{array}{c}\text { ANI } \\
\text { (This study) }\end{array}$ & $\begin{array}{c}\text { Malesia } \\
\text { (Bremekamp } \\
\text { 1955) }\end{array}$ & $\begin{array}{c}\text { Java } \\
\text { (Backer and } \\
\text { Bakhuizen van } \\
\text { den Brink } \\
\text { 1965) }\end{array}$ & $\begin{array}{c}\text { Australia } \\
\text { (Barker } \\
\text { 1986) }\end{array}$ & $\begin{array}{c}\text { New Guinea } \\
\text { (Barker 1986) }\end{array}$ & $\begin{array}{c}\text { ANI } \\
\text { (This study) }\end{array}$ & $\begin{array}{c}\text { Malesia } \\
\text { (Bremekamp } \\
\text { 1955) }\end{array}$ & $\begin{array}{c}\text { Java } \\
\text { (Backer and } \\
\text { Bakhuizen van } \\
\text { den Brink } \\
\text { 1965) }\end{array}$ & $\begin{array}{c}\text { Australia } \\
\text { (Barker } \\
\text { 1986) }\end{array}$ & $\begin{array}{c}\text { New } \\
\text { Guinea } \\
\text { (Barker } \\
\text { 1986) }\end{array}$ \\
\hline Axillary thorns & $\begin{array}{l}\text { Present or } \\
\text { absent, if } \\
\text { present always } \\
\text { facing upwards }\end{array}$ & Present & Present & $\begin{array}{l}\text { Usually } \\
\text { present }\end{array}$ & $\begin{array}{l}\text { Usually } \\
\text { present }\end{array}$ & $\begin{array}{l}\text { Present always, } \\
\text { facing } \\
\text { downwards }\end{array}$ & Present or not & Present or not & Absent & $\begin{array}{l}\text { Present or } \\
\text { not }\end{array}$ \\
\hline Inflorescences & $\begin{array}{l}\text { Both terminal } \\
\text { and axial }\end{array}$ & Terminal & Terminal & Terminal & Terminal & Terminal & Terminal & Terminal & Terminal & Terminal \\
\hline Bracteoles & $\begin{array}{l}\text { Present and } \\
\text { persistent }\end{array}$ & Present & Present & Present & Present & $\begin{array}{l}\text { Absent or } \\
\text { minute if } \\
\text { present, not } \\
\text { persistent }\end{array}$ & Usually absent & Usually absent & $\begin{array}{l}\text { Usually } \\
\text { absent }\end{array}$ & $\begin{array}{l}\text { Usually } \\
\text { absent }\end{array}$ \\
\hline Bract size & $0.8-1 \mathrm{~cm}$ & $0.7-0.9 \mathrm{~cm}$ & $0.7-0.9 \mathrm{~cm}$ & $0.65-0.8 \mathrm{~cm}$ & $0.65-0.82 \mathrm{~cm}$ & $0.3-0.5 \mathrm{~cm}$ & $0.3-0.6 \mathrm{~cm}$ & $0.3-0.4 \mathrm{~cm}$ & $0.65-0.82 \mathrm{~cm}$ & $0.65-8 \mathrm{~cm}$ \\
\hline Bracteole size & $0.5-0.8 \mathrm{~cm}$ & $\begin{array}{l}\text { More or less equal } \\
\text { to bracts }\end{array}$ & $0.6-0.8 \mathrm{~cm}$ & $0.6-0.8 \mathrm{~cm}$ & $0.55-0.65 \mathrm{~cm}$ & $0 . .3-0.5 \mathrm{~cm}$ & - & $0.3-0.4 \mathrm{~cm}$ & $\begin{array}{l}\text { Only } 1 \text { seen } \\
0.4 \mathrm{~cm}\end{array}$ & $\begin{array}{l}\text { Only } 1 \text { seen } \\
0.33 \mathrm{~cm}\end{array}$ \\
\hline Bract/bracteole apex & $\begin{array}{l}\text { Acute and } \\
\text { mucronate } \\
\text { mostly, obtuse } \\
\text { also }\end{array}$ & Spinose mucronate & - & $\begin{array}{l}\text { Often spine- } \\
\text { tipped }\end{array}$ & $\begin{array}{l}\text { Acute to } \\
\text { obtuse }\end{array}$ & $\begin{array}{l}\text { Bract apex is } \\
\text { obtuse and } \\
\text { bracteoles apex } \\
\text { is acute }\end{array}$ & - & - & Obtuse & Obtuse \\
\hline Corolla length & $3-4 \mathrm{~cm}$ & $3.5-4 \mathrm{~cm}$ & $3-4.5 \mathrm{~cm}$ & $2.2-3 \mathrm{~cm}$ & $2.8 \mathrm{~cm}$ & $0.9-1.5 \mathrm{~cm}$ & $1.5-3 \mathrm{~cm}$ & $2-3 \mathrm{~cm}$ & $2.2-2.6 \mathrm{~cm}$ & $2.2-2.4 \mathrm{~cm}$ \\
\hline Filament/stamen length & $2-2.5 \mathrm{~cm}$ & $1.5-2 \mathrm{~cm}$ & $1.3-1.6 \mathrm{~cm}$ & $1.1-1.3 \mathrm{~cm}$ & c. $1.3 \mathrm{~cm}$ & $1.2-1.5 \mathrm{~cm}$ & $0.7-1.2 \mathrm{~cm}$ & $0.75-1.25 \mathrm{~cm}$ & $1-1.1 \mathrm{~cm}$ & $1-1.1 \mathrm{~cm}$ \\
\hline Anther length & $0.8-1 \mathrm{~cm}$ & $0.8-0.85 \mathrm{~cm}$ & - & $0.63-0.65 \mathrm{~cm}$ & $0.62 \mathrm{~cm}$ & $0.3-0.5 \mathrm{~cm}$ & $0.4-0.6 \mathrm{~cm}$ & - & $0.6 \mathrm{~cm}$ & $0.5-0.65 \mathrm{~cm}$ \\
\hline Style length & $2.5-3 \mathrm{~cm}$ & $2.5 \mathrm{~cm}$ & $2.25-2.5 \mathrm{~cm}$ & $1.7-1.8 \mathrm{~cm}$ & $1.5-1.8$ & $0.8-1.2 \mathrm{~cm}$ & $1-1.5 \mathrm{~cm}$ & $2 \mathrm{~cm}$ & $1.2 \mathrm{~cm}$ & $1.2-1.8 \mathrm{~cm}$ \\
\hline Calyx length & $1.3-1.5 \mathrm{~cm}$ & $1.3 \mathrm{~cm}$ & $1.2-1.5 \mathrm{~cm}$ & $1.1-1.2 \mathrm{~cm}$ & $1.1-1.3 \mathrm{~cm}$ & $0.6-0.8 \mathrm{~cm}$ & $0.7-1.1 \mathrm{~cm}$ & $0.75-1.25 \mathrm{~cm}$ & $1-1.05 \mathrm{~cm}$ & $1-1.05 \mathrm{~cm}$ \\
\hline Suture of anther & Densely ciliate & Densely ciliate & - & $\begin{array}{l}\text { Ciliate along } \\
\text { one of both } \\
\text { sides }\end{array}$ & $\begin{array}{l}\text { Ciliate along } \\
\text { one of both } \\
\text { sides }\end{array}$ & Hairy & Densely ciliate & - & $\begin{array}{l}\text { Glabrous } \\
\text { along both } \\
\text { sides }\end{array}$ & $\begin{array}{l}\text { Ciliate } \\
\text { along one } \\
\text { side }\end{array}$ \\
\hline Corolla color & $\begin{array}{l}\text { Violet, light to } \\
\text { dark blue with } \\
\text { dark blue } \\
\text { median band }\end{array}$ & $\begin{array}{l}\text { Dark blue or violet, } \\
\text { rarely white }\end{array}$ & $\begin{array}{l}\text { Violet with } \\
\text { yellow median } \\
\text { band, rarely } \\
\text { white }\end{array}$ & $\begin{array}{l}\text { Blue, mauve, } \\
\text { whitish edged } \\
\text { with lilac }\end{array}$ & $\begin{array}{l}\text { Bright blue to } \\
\text { violet, } \\
\text { becoming } \\
\text { white, } \\
\text { internally with } \\
\text { yellow spot }\end{array}$ & White & White or pale blue & White & $\begin{array}{l}\text { Blue-purple, } \\
\text { dark blue, } \\
\text { purple, lilac, }\end{array}$ & $\begin{array}{l}\text { White with } \\
\text { blue } \\
\text { margins: } \\
\text { scented or } \\
\text { not }\end{array}$ \\
\hline
\end{tabular}


population of A. ilicifolius in the ANI as in other places however bract and bracteoles with obtuse apex are also observed in A. ilicifolius from Great Nicobar Islands. Axillary thorns and flower color in A. ebracteatus are consistent in the ANI but variable in other places. A. ebracteatus of the ANI have similar characteristics with specimen described in Java, but bracteoles are absent in Java but are minute in the ANI. Bract apex is obtuse in ANI and apexes of the bracteoles are acute. Most importantly two subspecies of A. ebracteatus described from Australia are more similar to A. ilicifolius described in this account except in the presence of glabrous anthers and flower color. It was reported that flower color of $A$. ilicifolius is rarely white (Jayatissa et al. 2002). In the present study A. ilicifolius with white flowers was not observed in the ANI, whereas flowers color in A. ilicifolius varied between light to dark violet. Recently Debnath et al. (2004) reported a new mangrove species Acanthus albus from Sundarbans. This new species is similar to $A$. ilicifolius except in flower color and smaller size of leaves, fruits and flowers. Similar kind of specimen was reported from Sri Lanka by Liyanage (1997) as A. volubilis, and later that it was confirmed as whitish flowered form of $A$. ilicifolius (Jayatissa et al. 2002). So the species status of $A$. albus has to be checked to avoid further complication in the identity of A. ilicifolius.

Acanthus ilicifolius was recorded at 46 sites out of 51 sites surveyed and observed in both Andaman Islands and Nicobar Islands whereas A. ebracteatus and A. volubilis were recorded at confined locations in the Andaman Islands. So it is reported that A. ebracteatus and $A$. volubilis are rare in these Islands. Earlier Dagar et al. (1991) reported the occurrence of $A$. ilicifolius and $A$. ebracteatus from Nicobar Islands but, in the present study, A. ebracteatus was not observed there. It has been reported that $62-70 \%$ of the mangrove forests of Nicobar Islands were destroyed by the submergence of coastal lands by about $1 \mathrm{~m}$ following the massive earthquake that occurred on 26th December 2004 (Ramachandran et al. 2005; Sridhar et al. 2006; Nehru and Balasubramanium 2011). It is suspected, therefore, that permanent submergence might have led to the extinction of A. ebracteatus from the Nicobar Islands, although this needs to be validated by more extensive and thorough surveys for Acanthus species in the Nicobar Islands.

Acanthus species has long been used as a traditional folk remedy for treating various ailments in Indian traditional medicine, traditional Tai medicine and Chinese traditional medicine (Wostmann and Liebezeit 2008; Saranya et al. 2015). Various parts of A. ilicifolius have been used as crude drug for treatment of asthma, diabetes, dyspepsia, leprosy, hepatitis, paralysis, snake bite, rheumatoid arthritis and diuretic (Bandaranayake 1998). The leaves of A. volubilis are used for dressing boils and wounds whereas powdered seeds are taken with water as a blood cleansing medicine and against ulcers (Das et al. 2013). The leaves of A. ebracteatus used for making Tai herbal tea in Thailand and Indonesia, as it has antioxidant properties (Chan et al. 2012). Capsule from A. ebracteatus, named Sea Holly Capsule, is a certified product of ministry of Public Health Thailand and has been used for relief of allergies and rashes (Saranya et al. 2015). In addition Acanthus species possess wide range of anti microbial activities (Ganesh and Vennila 2010) and various bioactive components have also been extracted (Bandaranayake 2002).

As per the IUCN Red data list all the three species of Acanthus are considered as of least concern. However, in India only A. ilicifolius is known to occur in all mangrove habitats except Lakshadweep, whereas $A$. ebracteatus and A. volubilis have very restricted distribution. A. ebracteatus was earlier known to occur only from Kerala and ANI (Kathiresan 2008), but Saravanan et al. (2008) reported its occurrence in Puducherry. But in recent times $A$. ebracteatus is not reported from Kerala. A. volubilis is present in ANI and Sundarbans, but in both the places its distribution is confined to a few locations. Hence $A$. ebracteatus and A. volubilis are confirmed as rare in India. So measures have to be taken to conserve these two species on priority basis.

\section{ACKNOWLEDGEMENTS}

We are extremely grateful to the Principal Chief Conservator of Forests, Andaman and Nicobar Islands for his guidance and ensuring necessary support from the field. We appreciate the cooperation and support provided by the CCF (Research and Working Plan), CCF, Territorial Circle and all the Divisional Forest Officers and their staff in the Department of Environment and Forests, Andaman and Nicobar Administration. Thanks are due to Dr. N. Krishnakumar, IFS, Director, Institute of Forest Genetics and Tree Breeding, Coimbatore for his support and encouragement. Special thanks are extended to DFO Campbell Bay for constant support.

\section{REFERENCES}

Anupama C, Sivadasan M. 2004. Mangroves of Kerala, India. Rheedea 14: $9-46$

Backer CA, Bakhuizen van den Brink RC. 1965. Acanthaceae. In: Flora of Java, vol. 2:5 44-593. P. Noordhof, Groningen, The Netherlands.

Bandaranayake WM, 1998. Traditional and medicinal uses of mangroves. Mangroves and Salt Marshes 2: 133-148.

Bandaranayake WM. 2002. Bioactivities, bioactive compounds and chemical constituents of mangrove plants. Wetlands Ecol Manag, 10: 421-452.

Barker RM. 1986. A taxonomic revision of Australian Acanthaceae. J Adelaide Bot Gard 9: 1-286.

Bremekamp CEB. 1955. The Acanthaceae of the Malesian area. Proc Kon Nederl Akad Wetensch, Ser C, 58:1. General Considerations: 162171. II. Special Part: 295-306.

Chan EWC, Eng SY, Tan YP, Wong ZC, Lye PY, Tan LN. 2012. Antioxidant and Sensory Properties of Thai Herbal Teas with Emphasis on Thunbergia laurifolia Lindl. Chiang Mai J Sci 39 (4): 599-609.

Dagar JC, Mongia AD, Bandhyopadhyay AK. 1991. Mangroves of Andaman and Nicobar Islands. Oxford and IBH, New Delhi.

Dagar JC, Singh NT. 1999. Plant Resources of the Andaman and Nicobar Islands. Introduction, General Features, Vegetation and Floristic Elements Vo. 1 and 2. Bishen Singh Mahendra Pal Singh, Dehra Dun.

Dagar JC. 1987. Mangrove vegetation, its structure, ecology, management and importance with special reference to Andaman and Nicobar 
Islands. In: Proceedings of the Symposium on Management of Coastal Ecosystems and Oceanic Resourcesof the Andamans, 17-18 July 1987, Andaman Sci Assoc, Central Agricultural Research Institute, Port Blair, India.

Dam Roy S, Krishnan P, George G, Kaliyamoorthy M, Goutham Bharath MP. 2009. Mangroves of Andaman and Nicobar Islands, A field guide. Central Agricultural Research Institute, Port Blair, India.

Das AK, Dev Roy MK. 1989. A General Account of the Mangrove Fauna of Andaman and Nicobar Islands. Fauna and Conservation Areas: 4 Published by the Director, Zoological Survey of India, Kolkata, India.

Das SS, Das S, Ghosh P. 2013. Optimization of DNA isolation and RAPD-PCR protocol of Acanthus volubilis Wall., a rare mangrove plant from Indian Sundarban, for conservation concern. Eur J Exp Biol 3 (6): 33-38

Debnath HS. 2004. Mangroves of Andaman and Nicobar Islands; Taxonomy and Ecology A Community Profile. Bishen Singh Mahendra Pal Singh, Dehradun.

Duke NC. 2006. Australia's mangroves: the Authoritative Guide to Australia's Mangrove Plants. University of Queensland and Norman C. Duke, Brisbane

Ganesh S, Vennila JJ. 2010. Screening for antimicrobial activity in Acanthus ilicifolius. Arch Appl Sci Res 2:311-315.

Goutham-Bharathi MP, Dam Roy S, Krishnan P, Kaliyamoorthy M, Immanuel T. 2014. Species diversity and distribution of mangroves in Andaman and Nicobar Islands, India. Botanica Marina 57: 421-432.

Jayatissa LP, Dahdouh-Guebas F, Koedam N. 2002. A review of the floral composition and distribution of mangroves in Sri Lanka. Bot J Linn Soc 138: $29-43$.

Kathiresan K. 2008. Biodiversity of mangrove ecosystems. Proceedings of Mangrove Workshop. GEER Foundation, Gujarat, India.

Kathiresan K. 2010. Importance of mangrove forest of India. J Coast Environ 1: 11-26.

Liyanage S. 1997. Mangrove plant communities in Sri Lanka. Forest Department, Colombo, Sri Lanka. [Original language: Sinhala; English translation].

Mall LP, Singh VP, Pathak SM, Garge A, Jat MS, Laskari M. 1987. Ecological studies of mangrove forest ecosystem of Andaman and Nicobar Islands. Final Technical Report. MAB project No.F 20/3/79 ENV., Vikaram University, Ujjain, India.

Mandal RN, Naskar KR. 2008. Diversity and classification of Indian mangroves: a review. Trop Ecol 49: 131-146.

Nehru P, Balasubramanian P. 2011. Re-colonizing mangrove species in tsunami devastated habitats at Nicobar Islands, India. Check List 7 253-256.
Parkinson CE. 1923. A Forest Flora of the Andaman Islands. Bishen Singh and Mahendrapal Singh, Dehradun.

Polidoro BA, Carpenter KE, Collins L, Duke NC, Ellison AM et al. 2010. The loss of species: Mangrove extinction risk and geographic areas of global concern. PLoS ONE 5: e10095. DOI: 10.1371/journal.pone.0010095

Ragavan P, Saxena M, Saxena A, Mohan P.M, Sachithanantham V, Coomar T. 2014. Floral composition and taxonomy of mangroves of Andaman and Nicobar Islands. Indian J Geo Mar Sci 43:1031-1044.

Ramachandran S, Anitha S, Balamurugan V, Dharanirajan K, Vendhan KE, Divien MIP, Vel AS, Hussain IS, Udayaraj A. 2005. Ecological impact of tsunami on Nicobar Islands (Camorta, Katchal, Nancowry and Trinkat). Curr Sci 89: 195-200.

Remadevi S, Binoj Kumar MS. 2000. Acanthus ebracteatus Vahl-An addition to the flora of Mainland of India. J Econ Taxon Bot 24 (1): 241-242.

Sahni KC. 1958. Mangrove forest in Andaman and Nicobar Islands. Indian Forester 84: 544-562.

Saranya A, Ramanathan T, Kesavanarayanan, Adam A. 2015. Traditional medicinal uses, chemical constituents and biological activities of a mangrove plant, Acanthus ilicifolius Linn.: A brief review. AmericanEurasian J Agric Environ Sci 15 (2): 243-250.

Saravanan KR, Ilangovan K, Khan AB. 2008. Floristic and macro faunal diversity of Pondicherry mangroves, South India. Trop Ecol 49: 9194.

Singh VP, Garge A. 1993. Ecology of Mangrove Swamps of the Andaman Islands. International Book Distributors, Dehradun, India.

Singh VP. 2003. Biodiversity, community pattern and status of Indianmangroves. In: Alsharhan AS, Fowler A, Goudie AS, Abdellatif EM, Wood WW (eds.) Desertification in the Third Millennium. Proceedings of an International Conference, Dubai. Taylor \& Francis,New York.

Sridhar R, Thangaradjou T, Kannan L, Ramachandran A, Jayakumar S. 2006. Rapid assessment on the impact of tsunami on mangrove vegetation of the Great Nicobar Island. J Indian Soc Rem Sens 34: 89-93.

Thothathri K. 1962. Contribution to the flora of Andaman and Nicobar Islands. Bull Bot Surv India 4: 281-296.

Wang WQ, Wang M. 2007. The Mangroves of China. Science Press, Beijing [Chinese].

Wostmann R, Liebezeit G. 2008. Chemical composition of the mangrove holly Acanthus ilicifolius (Acanthaceae)-review and additional data. Senckenbergiana Maritime 38: 31-37. 